\author{
Anatoliy Lutsyk \\ Taxation and Fiscal Policy Department/ PhD \\ Ternopil National Economic University \\ e-mail: luts_ai@yahoo.com \\ Viktoriya Kramar \\ Taxation and Fiscal Policy Department/ PhD Student \\ Ternopil National Economic University \\ e-mail: zvictoria@tane.edu.ua
}

\title{
ADAPTATION OF THE TAXATION SYSTEM OF UKRAINE TO THE REQUIREMENTS OF EUROPEAN UNION
}

\begin{abstract}
In the research the problematic aspects of the national taxation system functioning are considered. The recommendations for the national taxation harmonization are given.
\end{abstract}

Key words: taxation system, shadow economy, tax regulation function, tax administration.

\section{Introduction}

The experience of the taxation system development when Ukraine became an independent country shows that the tax regulation of the economic relations only by changing different tax rates, implementation of the new taxes, fees and tax-credits for a certain group of tax-payers doesn't lead to the formation of clearly defined tax system.

A great percentage of every country's success belongs to the system of tax administration through which the real inter-relation of the state and tax-payers are implemented. That is why the international experience in many aspects can be very useful for Ukraine.

Unlike the countries of Central and Eastern Europe, in Ukraine as well as in other former members of the Soviet Union (except for Russia) the process of taxation system formation coincided with the development of independence and civil society. These processes became the important limiting factor, as the developed taxation forms that could be efficient only in the strong legal society conditions were transferred directly to the inadequate basement of the weak state power. 